\title{
Behind the Screen
}


This page intentionally left blank 


\section{Behind the Screen}

Content Moderation in the Shadows

of Social Media

SARAH T. ROBERTS

Yale UNIVERSITY PREsS

New Haven and London 
Copyright (C) 2019 by Sarah T. Roberts.

All rights reserved.

This book may not be reproduced, in whole or in part, including illustrations, in any form (beyond that copying permitted by Sections 107 and 108 of the U.S. Copyright Law and except by reviewers for the public press), without written permission from the publishers.

Yale University Press books may be purchased in quantity for educational, business, or promotional use. For information, please e-mail sales.press@yale.edu (U.S.office) or sales@yaleup.co.uk (U.K. office).

Set in Minion type by IDS Infotech Ltd.

Printed in the United States of America.

ISBN 978-0-300-23588-3 (hardcover : alk. paper)

Library of Congress Control Number: 2018963972

A catalogue record for this book is available from the British Library.

This paper meets the requirements of ANSI/NISO Z39.48-1992 (Permanence of Paper).

10987654321 
For my grandparents

For my parents

For Patricia 
"'Human-Computer Interaction' ... I mean, what other kind is there?"

-DR. CHRISTINE PAWLEY, 2009 